\title{
THIOURACIL. ITS ABSORPTION, DISTRIBUTION, AND EXCRETION ${ }^{1}$
}

\author{
By ROBERT H. WILLIAMS, GLORIA A. KAY, AND BERNARD J. JANDORF 2 \\ (From the Thorndike Memorial Laboratory, Second and Fourth (Harvard) Medical Services, Boston \\ City Hospital, and the Department of Medicine, Harvard Medical School, Boston)
}

(Received for publication August 4, 1943)

In a previous paper (1), we have mentioned various studies dealing with thioureas and sulfonamides which have led to the use of one of the thiourea derivatives, thiouracil, in the treatment of patients with thyrotoxicosis $(2,3)$. Evidence continues to accumulate that when this drug is administered to patients or experimental animals, the production of thyroid hormone is inhibited, resulting in a fall of the basal oxygen consumption, increased activity of the anterior pituitary, and consequent hyperplasia of the thyroid gland. We have also pointed out (1) the importance of knowing more about the pharmacological properties of this drug, particularly the rate of absorption and excretion and its metabolism. For these studies, we found that it was necessary to establish methods for the estimation of this substance in tissues and body fluids. The methods which we found suitable (1) are based on Grote's observation (4) that a color develops when substances of a $\mathrm{C}=\mathrm{S}$ type are treated with a special sodium nitroferricyanide reagent. Thiouracil ${ }^{3}$ has the $\mathrm{C}=\mathrm{S}$ linkage and we found that it gives a greenish color which can be estimated by means of an Evelyn photoelectric colorimeter. We refer the reader to our previous report (1) for a consideration of the specificity of the method. However, we wish to state here that whereas we have not proved directly that all of the color obtained is attributable to thiouracil, the evidence strongly suggests that such is the case.

\section{ABSORPTION AND EXCRETION}

In conducting the experiments relating to the absorption and excretion of thiouracil the following points were investigated:

\footnotetext{
1 This investigation was aided by a grant from the Milton Fund of Harvard University.

2 Fellow of the Commonwealth Fund.

The thiouracil was supplied by the Lederle Laboratories, Inc., Pearl River, New York.
}

(1) The rate of disappearance of the drug from the gastro-intestinal tract.

(2) The quantity broken down in the stomach and intestines, either by enzymes or by bacteria.

(3) The proportion of thiouracil excreted as such in the stools.

(4) The interval between its ingestion and its appearance and accumulation in the blood and urine.

(5) The frequency of administration and the total dosage necessary to establish and maintain a constant level in the blood stream and a constant rate of excretion in the urine.

(6) The interval between the discontinuation of treatment with the drug and its disappearance from the excreta.

(7) The proportion of the total amount of thiouracil ingested which is recoverable from the urine and feces.

A few of the studies were found to be conveniently performed with rats, but most of them were carried out in man.

\section{Experiments with rats}

The rats used were of the Wistar strain. They weighed about 200 grams and were not fasted.

The purpose of the first experiment was to determine the rate of absorption of thiouracil from the gastro-intestinal tract and the segments from which it is absorbed. Each of 3 rats was given $5 \mathrm{cc}$. of a $20 \mathrm{mgm}$. per cent solution of thiouracil by means of a stomach tube. Two hours later the animal was killed by a blow on the head and sutures were placed in such a manner as to isolate the stomach, duodenum, jejunum, and ileum. These segments were ground and their content of thiouracil was determined (Table I). A small portion of the drug was found in various segments, but from 76 to 91 per cent of the amount ingested had disappeared.

In another experiment, using ether anesthesia, 
TABLE I

Disappearance of thiouracil from the gastro-intestinal tract

Percentage of total drug ingested remaining after 2 hours

\begin{tabular}{l|r|c|c}
\hline \multicolumn{1}{c|}{ Site } & Rat 1 & Rat 2 & Rat 3 \\
\cline { 2 - 3 } Stomach & 16 & 0 & 5 \\
Duodenum & 3 & 0 & 0 \\
Jejunum & 0 & 9 & 0 \\
Ileum & 5 & 2 & 4 \\
\hline
\end{tabular}

the proximal and distal lumina of the stomach, duodenum, and jejunum of 4 rats were occluded with sutures. Care was taken to avoid unnecessary trauma. Into each isolated segment was injected $1 \mathrm{cc}$. of a $20 \mathrm{mgm}$. per cent solution of thiouracil. A very small needle was used for injecting and the site of injection was immediately cauterized with a hot rod. At intervals of 1,2 , and 3 hours later, the animals were killed by means of a blow on the head and the amount of thiouracil remaining in the segments was determined (Table II). The drug was found to disappear rapidly from the stomach, duodenum, and the jejunum, in most instances more than 80 per cent having disappeared. In one animal, none of the drug remained in any segment at the end of 2 hours. However, this does not necessarily mean that all of the thiouracil had been absorbed; some of it may have been broken down by gastro-intestinal enzymes or by bacteria. Consequently, we investigated these possibilities by incubating a known amount of thiouracil with the contents of the gastro-intestinal tract. Four non-fasted rats were anesthetized with ether and, by means of sutures, the stomach, duodenum, jejunum, and ileum were isolated. Immediately thereafter, $0.5 \mathrm{mgm}$. of pilocarpine hydrochloride was injected subcutaneously. At intervals of 1 , 2 , and 2.5 hours, the animals were killed and the contents of the isolated segments were removed. To the contents was added enough of a $20 \mathrm{mgm}$. per cent solution of thiouracil to make a final concentration of from 4 to $10 \mathrm{mgm}$. per cent. The mixture was incubated at $37^{\circ} \mathrm{C}$., the interval being 12 hours in the case of 2 animals and 2 hours in the case of the other 2 . The stomach contents produced an average destruction of $\mathbf{4 2}$ per cent of the added thiouracil (Table III). The duodenal, as well as the jejunal contents, caused an even greater destruction, whereas the ileal material had no effect in any experiment. Therefore, the disappearance of the thiouracil from the isolated segments of the gastro-intestinal tract may have been partially due to destruction of the drug, rather than being due entirely to absorption.

Further studies were conducted to determine more definitely the amount of drug absorbed from the gastro-intestinal tract and the amount destroyed therein. Eleven rats were given $5 \mathrm{cc}$. of $100 \mathrm{mgm}$. per cent thiouracil through a stomach tube and one hour later they were killed by a blow on the head. Immediately thereafter, the gastro-intestinal tracts of 7 animals were removed, without spilling any of the contents, and the total amount of thiouracil was determined in 4 cases. The carcasses of these 7 animals, as well as those of the 4 rats with the gastrointestinal tract intact, were homogenized by means of a sausage grinder and a Waring blendor and the total amount of thiouracil was determined. All urine passed during the hour was added to the carcass mixture. In analyzing the results, we have considered the amount of the drug unaccounted for as being the maximal amount destroyed in the gastro-intestinal tract. However, the actual quantity destroyed is, no doubt, somewhat less than this since the recovery

TABLE II

Rate of disappearance of thiouracil injected into isolated segments of gastro-intestinal tract

\begin{tabular}{|c|c|c|c|c|}
\hline Hours. . . . . . . . & 1 & 2 & 2 & 3 \\
\hline & \multicolumn{4}{|c|}{ Percentage of disappearance } \\
\hline $\begin{array}{l}\text { Stomach } \\
\text { Duodenum } \\
\text { Jejunum }\end{array}$ & $\begin{array}{l}85 \\
85 \\
38\end{array}$ & $\begin{array}{l}100 \\
100 \\
100\end{array}$ & $\begin{array}{r}10 \\
40 \\
100\end{array}$ & $\begin{array}{l}85 \\
96 \\
99\end{array}$ \\
\hline
\end{tabular}

TABLE III

Rate of destruction of thiouracil incubated with the contents of segments of the gastro-intestinal tract

\begin{tabular}{l|r|r|r|r}
\hline \hline Hours.......... & 1 & 2 & 2.5 & 2.5 \\
\cline { 2 - 4 } & \multicolumn{4}{|c}{ Percentage of destruction } \\
\hline Stomach & 41 & 43 & 45 & 40 \\
Duodenum & 68 & 78 & 70 & 51 \\
Jejunum & 75 & 0 & 88 & 41 \\
Ileum & 0 & 0 & 0 & 0 \\
\hline
\end{tabular}


of the drug is probably not quite 100 per cent and since some destruction may have taken place in the tissues (see below). Nevertheless, there is no question that the least amount of the drug absorbed was the quantity found in the carcasses without the gastro-intestinal tract. This quantity, although variable, tended to be about 50 per cent of the amount administered (Figure 1). The amount destroyed was in most instances less than 25 per cent.

\section{Clinical observations}

The amount of thiouracil remaining in the gastro-intestinal tract at autopsy was studied in 3 cases. At the time that the drug treatment was instituted, death was imminent in each case. One patient had nephritis and was given only one dose, 1 gram administered 10 hours before death. Each of the other patients had a cerebral hemorrhage and was given 0.2 gram at intervals of 4 hours for 2 to 3 days. The last dose in each case was administered about 4 hours before death. At autopsy, a small amount of the drug, less than 25 mgm., was found in the stomach and duodenum of each case but none was found in the jejunum. These findings indicate that absorption is rapid in spite of a moribund state and that possibly all of the drug is absorbed (or destroyed) before it reaches the jejunum.

A normal man, aged 32 , was given 0.2 gram of thiouracil by mouth. At the time of the medication, he was in a fasting state and was not permitted to eat until 2 hours later. Blood specimens were obtained, following the ingestion of the drug, at 15 and 30 minutes, hourly intervals for 4 hours, 2 -hour intervals for 8 hours, and at 1,2 , and 3 days. All urine was saved and collected at about the same time as the blood specimens. The highest blood level, $2.3 \mathrm{mgm}$. per $100 \mathrm{cc}$, was attained in the 15-minute specimen (Figure 2). Thereafter, it began to fall, reaching a relatively low value within 8 hours, $0.3 \mathrm{mgm}$. per $100 \mathrm{cc}$., remaining at about this level until the end of the third day when no more of the drug was found. A small amount of thiouracil was found in the 30 -minute specimen of urine. The maximal excretion, $15 \mathrm{mgm}$., occurred during the second hour; thereafter the excretion progressively decreased, less than 3

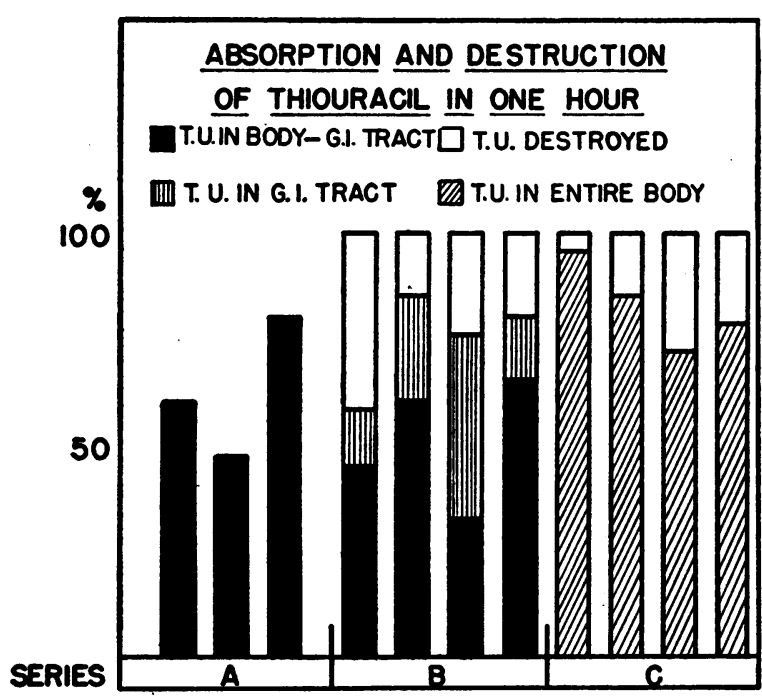

Fig. 1. Absorption and Destruction of Thiouracil IN ONE HOUR

Each column represents in one rat the percentage of the total amount (5 mgm.) of thiouracil (T.U.) given intragastrically, which was recovered from the body and the gastro-intestinal (G.I.) tract one hour later. In series A was determined the thiouracil content of the body without the gastro-intestinal. tract. In series $B$, the gastrointestinal tract was also examined, while in series $C$ the entire animal was analyzed as one specimen. Note that the absorption of the drug by the body tends to be greater than 50 per cent and the destruction is less than 25 per cent. These must be minimal and maximal averages, respectively, for reasons discussed in the text.

mgm. being excreted during the second and third days. Throughout the period of observation, only $94 \mathrm{mgm}$., or 47 per cent of the dose administered, was excreted in the urine.

The normal subject, mentioned above, was used in another study 3 weeks later. He was given 0.2 gram of thiouracil every 4 hours for 3 days. Blood and urine samples were obtained at frequent intervals throughout a period of 7 days, as illustrated in Figure 3. After 12 hours, the blood level remained relatively stationary, 2.5 to $3 \mathrm{mgm}$. per $100 \mathrm{cc}$., but it showed a marked drop 16 hours after discontinuing the drug. Essentially all of the drug had disappeared from the blood stream within 48 hours after cessation of treatment. A maximum rate of excretion of the drug in the urine occurred during the 4- to 8hour interval, $75 \mathrm{mgm}$. being excreted. Four hours after discontinuing the use of thiouracil, the rate of its excretion began to decline rapidly; 


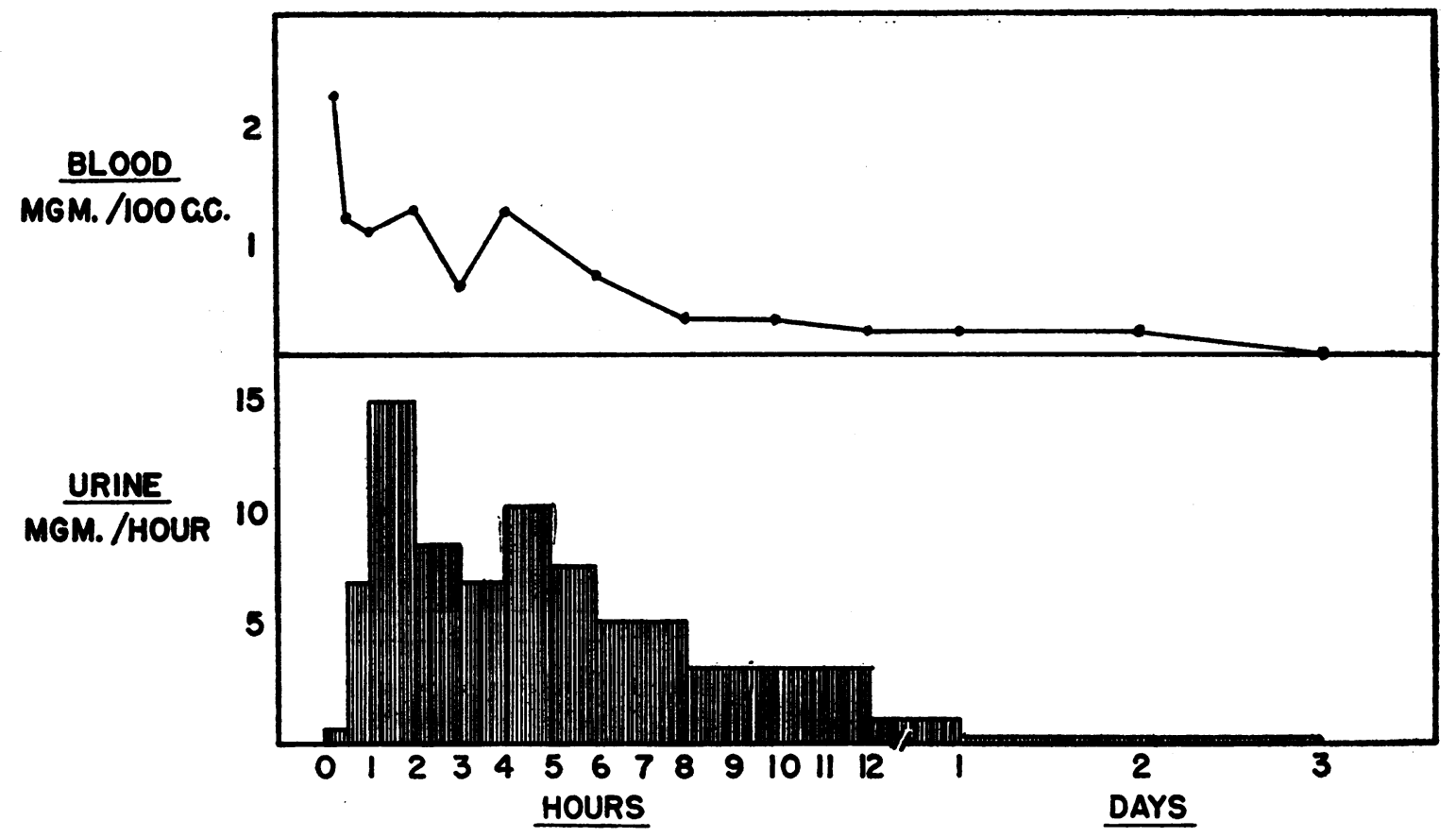

Fig. 2. The Amounts of Thiouracil in the Blood and Urine of a Normal Individual Following THE INGEstion of 0.2 GRAM OF THE DRUg

however, it did not disappear from the urine until 4 days later. Throughout the period of observation, only 1.3 grams, or 34 per cent of the total amount of thiouracil ingested, was excreted in the urine.

A man aged 42, who was normal except for marked obesity and mild diabetes, was given 0.2 gram of thiouracil every 4 hours. Blood and urine specimens were obtained at hourly intervals for 8 hours, at 2-hour intervals for 4 hours, and daily thereafter for 6 days. Thirty minutes after the first dose the blood was found to contain $2.3 \mathrm{mgm}$. per $100 \mathrm{cc}$. (Figure 4), but within another 30 minutes, it had fallen to $1.2 \mathrm{mgm}$. per $100 \mathrm{cc}$., remaining at this approximate level until the next dose was given. One hour after the second dose, the concentration was $3 \mathrm{mgm}$. per $100 \mathrm{cc}$., but thereafter continued to fall until the third dose was administered. However, after the first 24 hours, the level was found to remain relatively constant during the 5 days that it was followed. Small amounts of thiouracil were excreted in urine during the 20 minutes following the ingestion of the first dose of the drug, and there tended to be a progressive in- crease in the rate of excretion until the end of the first 24 hours. For the next 5 days, the rate of excretion remained strikingly constant, being about $510 \mathrm{mgm}$. per day.

In Figure 3 are plotted the concentrations of thiouracil in the whole blood of 8 individuals. Subject 5 was a normal man, subject 8 had mildly active rheumatic fever, subject 3 had mild diabetes, and the other 5 had thyrotoxicosis. Some variability in the rate of elevation of the blood level is observed; however, a relatively constant level was reached in most instances within 24 to 48 hours. The responses to the smaller doses were not very different from the responses to the large one. It is of interest to point out that the peaks in patient 1 (Figure 5) represent specimens obtained at 9 a.m., whereas the alternate low levels represent specimens taken at 9 p.m. The interval of time from the previous dosage of thiouracil was 4 hours in each instance. We have observed in other cases that the blood level sometimes drops following a meal, particularly the night meal. A possible explanation of this phenomenon is discussed later.

In Figure 6 are plotted the total daily excre- 


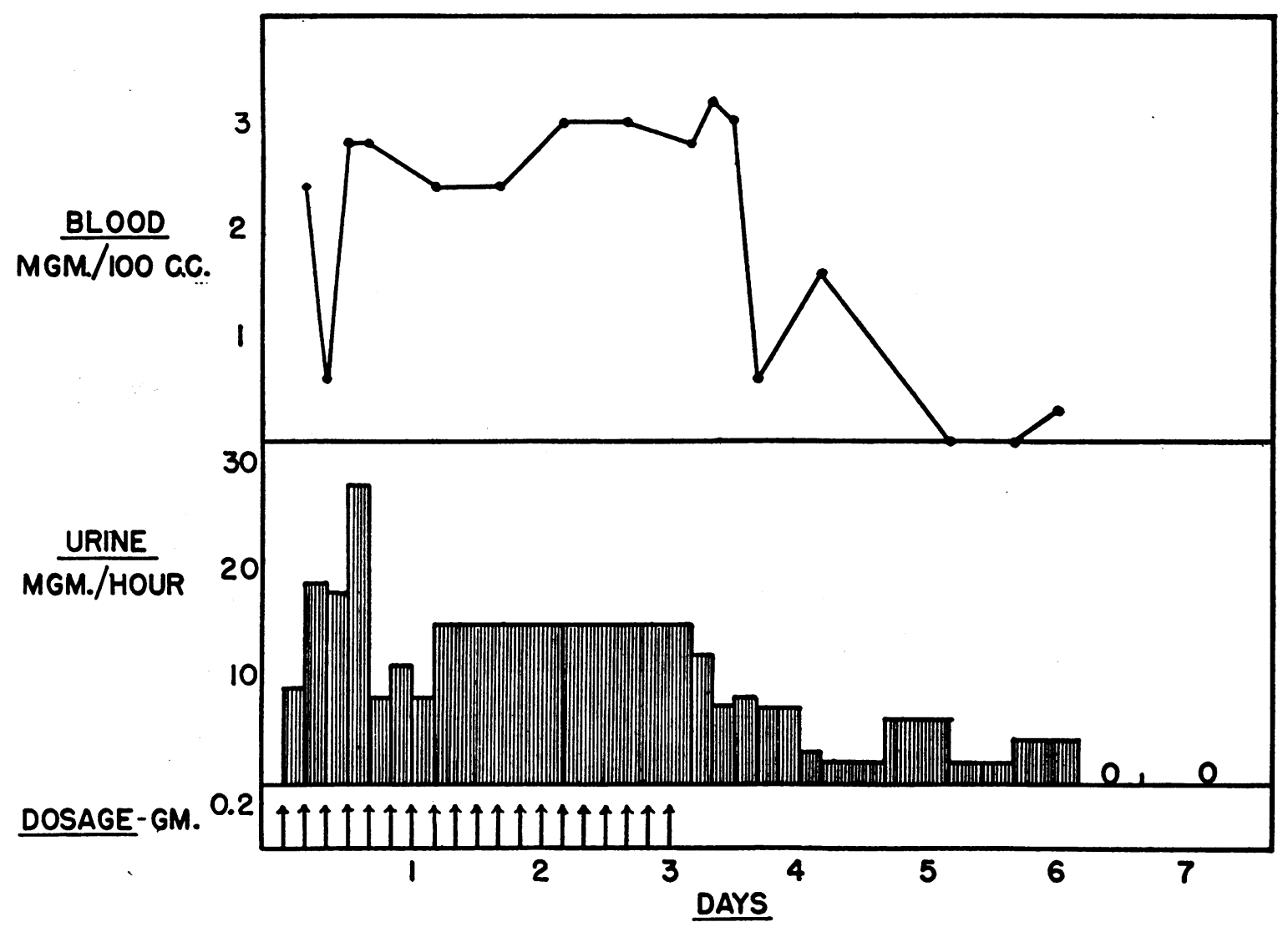

Fig. 3. The Amounts of Thiouracil in the Blood and Urine of a Normal Individual During and Following the Ingestion of 0.2 gram of the Drug Every 4 Hours for 3 Days

tions of thiouracil in the urine of 12 individuals. Subjects 5 and 7 had untreated myxedema, subjects 9 and 10 were normal, and the others had thyrotoxicosis. There was an interval of 24 to 48 hours before the amount of the thiouracil excreted reached a relatively constant level. This was true in the cases receiving the smaller dosages as well as in the cases with the larger dosages. The total excretion in the latter group was greater than in the former; however, the total amount of the drug excreted by any subject was only about one-third of the quantity ingested.

In a few cases, we had the opportunity of following, daily, the changes in the concentration of thiouracil in the blood and urine after discontinuing the administration of the drug. A knowledge of these changes is important in relation to the development of possible complications from this substance and is also of aid in calculating the percentage of the administered drug which is excreted in the urine. One subject who had received 1.2 grams ${ }^{4}$ daily for 3 days was found to have a blood level of $1.6 \mathrm{mgm}$. per $100 \mathrm{cc}$., 24 hours after discontinuation of the drug. On the following day, none was present. Another patient who had received 1.0 gram daily for 4 weeks was shown to have the following levels on successive days after stopping treatment: 2.5 , $0.6,0.4,0.0 \mathrm{mgm}$. per $100 \mathrm{cc}$. of blood. A third patient who had received 1.0 gram daily for 4 weeks had only traces of thiouracil in the blood 5 days after stopping treatment. A fourth patient, having received 0.8 gram daily for 3 weeks, was found to have no thiouracil in the blood 48 hours after discontinuing therapy. However, in this case, fluids were forced to 5 liters daily.

4hroughout this paper, unless otherwise specified, the daily dosage given consists of single doses of 0.2 or 0.25 gram, administered at evenly-spaced intervals throughout the 24-hour period. 


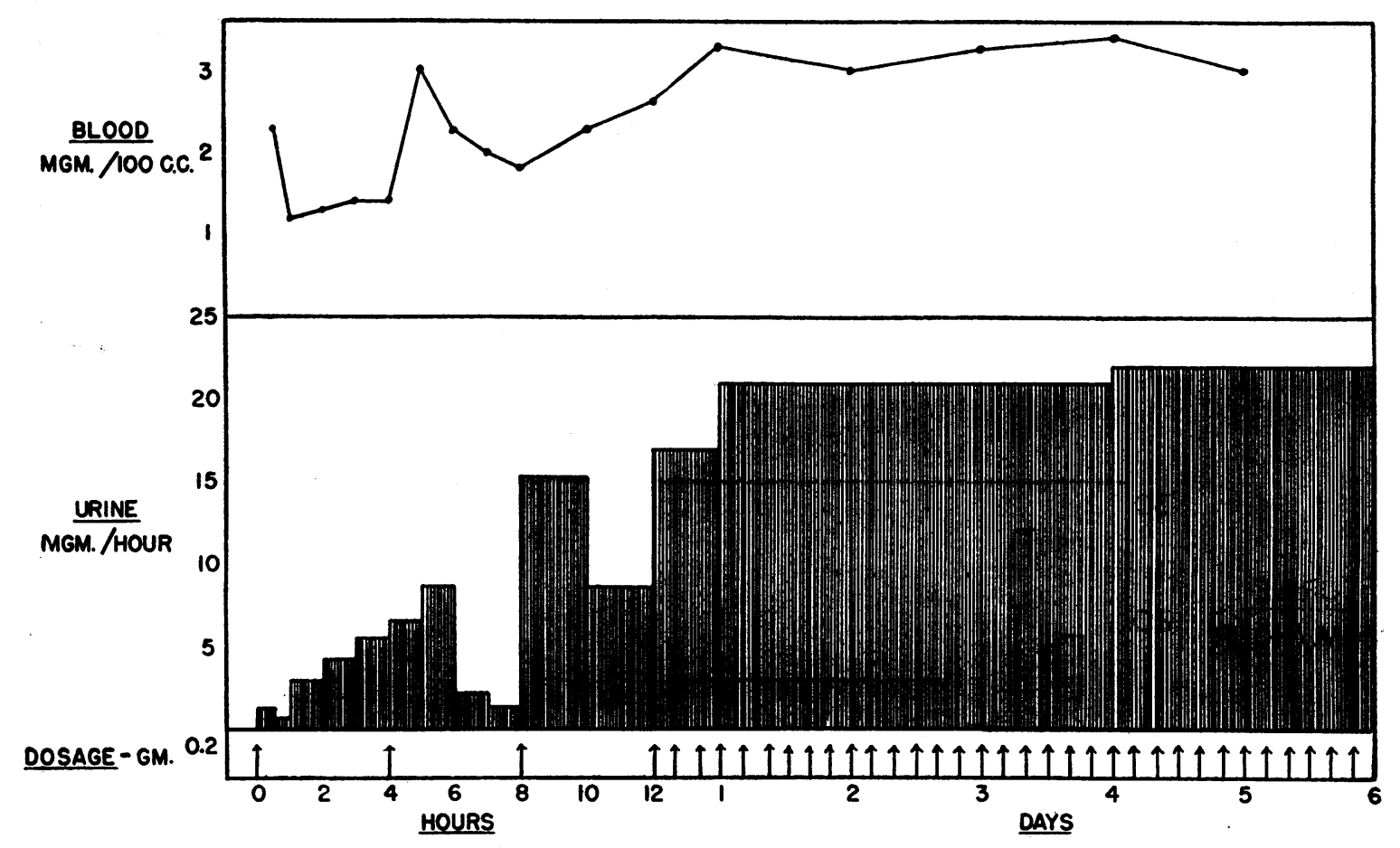

Fig. 4. The Amounts of Thiouracil in the Blood and Urine of an Obese Individual During the Ingestion of 0.2 gram of Thiouracil Every 4 Hours

Note the constancy of the blood level and renal excretion after the first day.

In 5 patients, we studied the rate of disappearance of thiouracil from the urine, following cessation of treatment. Four of these patients had received 0.8 gram or 1 gram daily for 3 or 4 weeks. The other patient had received treatment for only 3 days, the dosage being 1.2 grams daily. In this patient, all thiouracil had disappeared within 4 days. In the 4 cases receiving the more prolonged treatment, the urine did not become free of thiouracil until from 5 to 7 days. The total amount excreted following discontinuation of the drug just about equaled the usual daily content of the urine. For example, in 1 patient who for several days had excreted about 225 mgm. per day, with the cessation of treatment the daily excretion was as follows: $157 \mathrm{mgm}$., 33 mgm., 18 mgm., 8 mgm., $8 \mathrm{mgm}$., 0 mgm. Since the amount of thiouracil excreted in the urine was repeatedly found to be only about one-third of the amount ingested, we investigated the quantity eliminated in the feces. All of the stool specimens of 4 patients receiving 1.2 grams of thiouracil daily were saved for a period of 4 days. None of the drug was recovered from any of the specimens. The failure to find the substance in the stools could be attributed, in large part, to absorption and destruction of the drug high in the intestinal tract, the evidence for which we have given. Nevertheless, the question was raised as to whether colon bacilli break down thiouracil. For this reason, we studied the effects of $E$. coli, staphylococcus aureus, and beta hemolytic streptococcus on this drug. To heavy broth cultures of each of these organisms was added enough thiouracil to make a concentration of $4 \mathrm{mgm}$. per $100 \mathrm{cc}$. The mixture was incubated at $37^{\circ} \mathrm{C}$. for 24 hours. The colon bacilli caused no destruction of the drug, while the staphylococci caused destruction of 35 per cent, and the streptococci caused destruction of 50 per cent.

In order to estimate the amount of thiouracil broken down in the body in sites other than the gastro-intestinal tract, $500 \mathrm{mgm}$. of the drug (in the form of its sodium salt) were given in $10 \mathrm{cc}$. of saline, intravenously, to each of 3 normal sub- 


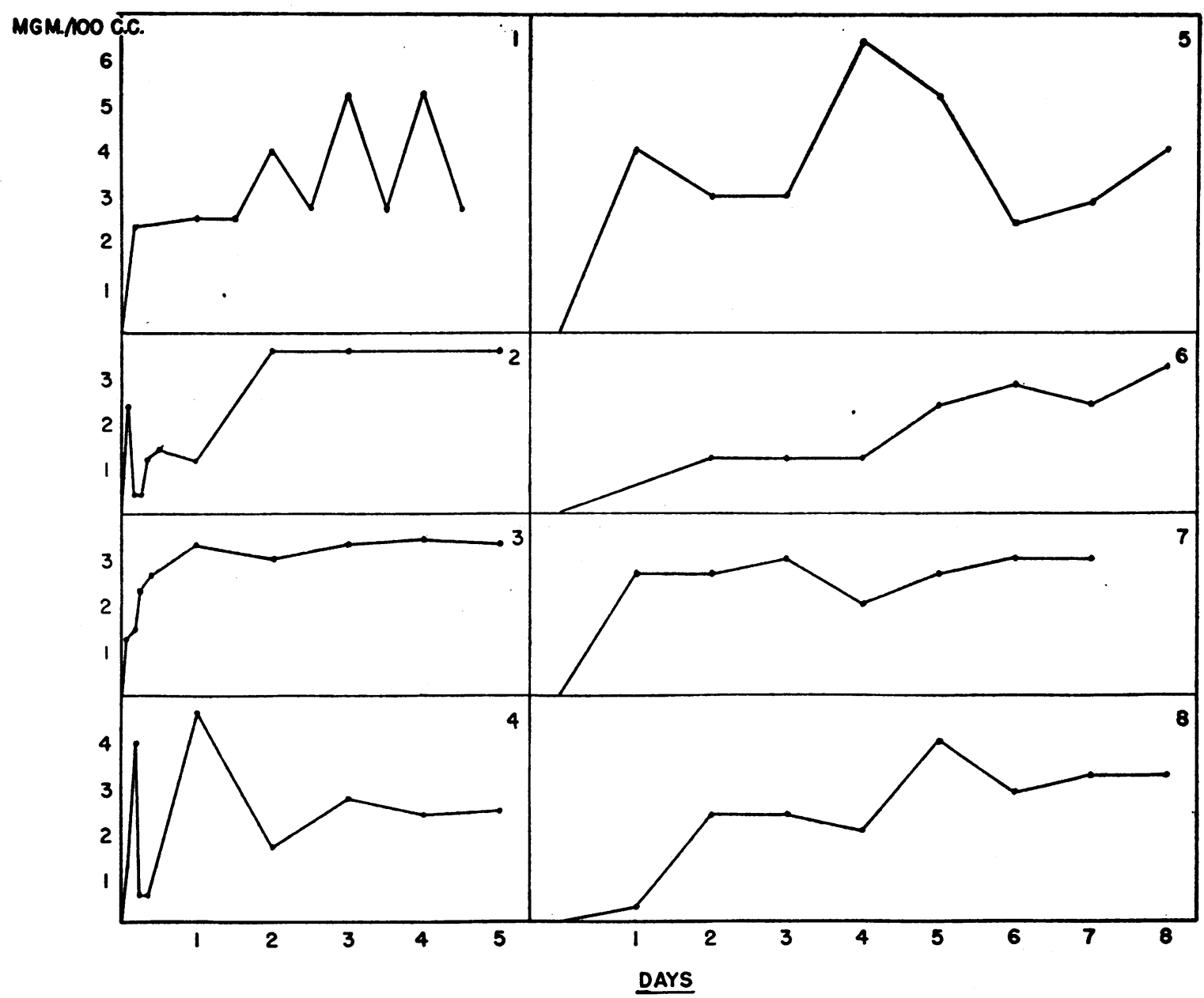

Fig. 5. The Rate of Accumulation of Thiouracil in the Blood

The daily dosage for patients 1, 2, and 3 was 1.2 grams; for patients 4 and 5, 0.6 gram; for patients 6 and 7, 0.4 gram; and for patient 8 , it was 0.2 gram.

jects. A total of from 41 to 50 per cent of the injected dose was excreted in the urine.

Comparative studies with thiourea have shown that following the injection of $500 \mathrm{mgm}$. of this substance, intravenously, approximately onethird of the injected dosage is excreted in the urine. The question now arises as to what are the other excretion products of these thiourea substances. Various investigators $(5,6)$ have found, in man and animals fed thiourea, that almost all of this substance was excreted in the urine in the form of organic sulfur compounds. It seems likely, therefore, that part of the administered thiourea, at least, is transformed in the body in such a way that its sulfur, while still in organic combination, no longer forms a part of the group $\mathrm{N}-\mathrm{C}-\mathrm{N}$ which gives the color with Grote's reagent, at a $\mathrm{pH}$ of from 8.5 to 9 . In the case of thiouracil, Mendel and Myers (7) have found that when this substance is fed to dogs, the urine gives a strong qualitative test, which is apparently specific for uracil and cytosine. We are now conducting studies of the specific excretion products of thiouracil which we hope to report at a later date (8). 


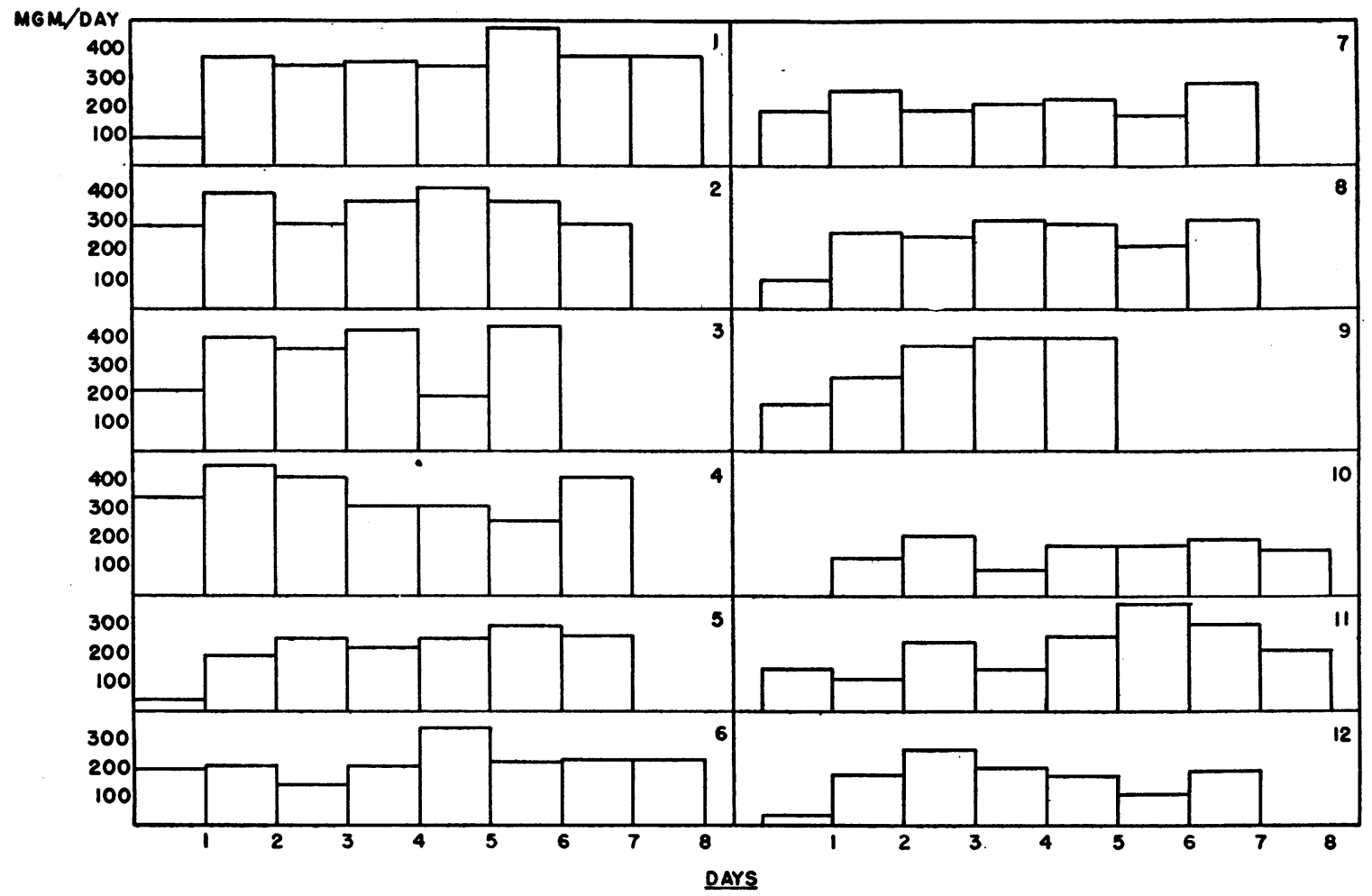

Fig. 6. The Rate of Excretion of Thiouracil in the Urine from the Beginning of Treatment

The daily dosage for patients 1 to 4 was 1.2 grams; for patients 5 to $9,1.0 \mathrm{gram}$; for patients 10 to $11,0.6 \mathrm{gram}$; and for patient 12, 0.4 gram.

\section{DISTRIBUTION OF THIOURACIL IN BODY FLUIDS}

In a group of patients, mostly thyrotoxics, receiving treatment with thiouracil, we made repeated determinations of the content of this substance in the blood, in order to determine the concentration obtained by various dosages of the drug. A summary of these results is recorded in

TABLE IV

Concentration of thiouracil in the blood

\begin{tabular}{l|c|c|c|c}
\hline \hline \multirow{2}{*}{$\begin{array}{c}\text { Daily } \\
\text { dosage }\end{array}$} & \multicolumn{2}{|c|}{ Blood level } & \multirow{2}{*}{$\begin{array}{c}\text { Number of } \\
\text { determina- } \\
\text { tions }\end{array}$} & $\begin{array}{c}\text { Number of } \\
\text { patients }\end{array}$ \\
\cline { 2 - 3 } grams & Average & Range & & \\
\cline { 2 - 3 } 1.2 & \multicolumn{2}{|c|}{ msm. per 100 cc. } & & \\
1.0 & 3.3 & 1.2 to 5.2 & 17 & 6 \\
0.8 & 2.5 & 0.8 to 4.0 & 12 & 8 \\
0.75 & 2.6 & 2.0 to 2.8 & 6 & 4 \\
0.6 & 2.4 & 1.2 to 5.2 & 21 & 9 \\
0.5 & 3.0 & 2.4 to 6.4 & 17 & 10 \\
0.4 & 2.7 & 1.2 to 5.2 & 13 & 6 \\
0.25 & 2.0 & 0.8 to 3.2 & 25 & 11 \\
0.2 & 1.8 & 1.2 to 2.4 & 11 & 4 \\
\hline
\end{tabular}

Table IV. The values given are only those obtained after the patient had been on the stated dosage for more than 3 days. It was believed that, during this interval, the blood level would become relatively stabilized. Although 9 different dosage levels were given, varying from 0.2 to 1.2 grams daily, the average blood level was found to be about $2.5 \mathrm{mgm}$. per $100 \mathrm{cc}$. in nearly all. The concentration of thiouracil in the blood was found to vary somewhat in the same individual, although the blood specimen was obtained at the same time of day, with the patient fasting, receiving his medications at regular intervals, and under other such standard conditions on a metabolic ward.

The distribution of thiouracil in different elements of the blood was studied in 4 individuals who had been treated with this substance for several days (Table $\mathrm{V}$ ). In 3 subjects, the blood cells were found to contain about 7 times as-much as the plasma; in the other subject, the cells contained twice as much as did the plasma. The 
TABLE V

Distribution of thiouracil in the blood

\begin{tabular}{|c|c|c|c|c|c|}
\hline \multicolumn{2}{|c|}{ 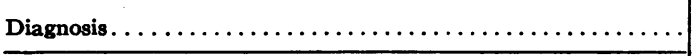 } & Normal & Obesity & Thyrotoxicosis & Hypertension \\
\hline \multicolumn{2}{|c|}{ Daily dosage of thiouracil (grams) } & 1.0 & 1.2 & 1.2 & 0.5 \\
\hline $\begin{array}{l}\text { Thiouracil (mgm. per } \\
100 \text { cc. of whole blood) }\end{array}$ & $\begin{array}{l}\text { White blood cells } \\
\text { Red blood cells } \\
\text { Total cells } \\
\text { Plasma }\end{array}$ & $\begin{array}{l}0.50 \\
1.25 \\
2.0 \\
0.29\end{array}$ & $\begin{array}{l}0.63 \\
2.29 \\
2.98 \\
0.42\end{array}$ & $\begin{array}{l}0.92 \\
1.83 \\
2.8 \\
0.39\end{array}$ & $\begin{array}{l}0.008 \\
3.8 \\
3.7 \\
1.8\end{array}$ \\
\hline Hematocrit (per cent) & $\begin{array}{l}\text { White blood cells } \\
\text { Red blood cells } \\
\text { Plasma }\end{array}$ & $\begin{array}{r}0.1 \\
28.5 \\
71.4\end{array}$ & $\begin{array}{r}0.1 \\
37.3 \\
62.6\end{array}$ & $\begin{array}{r}0.1 \\
35.0 \\
64.9\end{array}$ & $\begin{array}{r}0.1 \\
40.0 \\
59.9\end{array}$ \\
\hline \multicolumn{2}{|l|}{ White blood cell count } & 8,950 & 8,200 & 6,200 & 8,200 \\
\hline
\end{tabular}

red blood cells were found to possess 2 or more times the amount present in the white blood cells. However, the average amount of drug per cell was much greater in the white cells than in the red.

Further experiments were conducted on the absorption of thiouracil by the blood cells, in vitro. Fifty cc. of blood were obtained from each of 5 patients, of whom one was convalescing from a coronary occlusion, one had obesity, one had acute myelogenous leukemia, one had chronic myelogenous leukemia, and one had chronic lymphogenous leukemia. To the blood were added 10 drops of a 20 per cent solution of potassium oxalate and enough of a $20 \mathrm{mgm}$. per cent solution of thiouracil to make a final concentration of about $4 \mathrm{mgm}$. per cent. The mixture was incubated at $38^{\circ} \mathrm{C}$. for one hour and immediately thereafter the estimations of thiouracil were begun. It may be observed in Table VI that the higher the white count, the larger the amount of the drug found in the white cells, whether the cells were almost entirely lymphocytes, or whether they were granulocytes. Although the average quantity of thiouracil removed by individual granulocytes was greater than that removed by lymphocytes, the latter cells absorbed more of the drug in comparison to their size. The white cells of the acute leukemic patient removed the same amount per. volume of cells as did the chronic myelogenous leukemic cells, but the amount per cell was less in the former group. The red cells of the leukemic pateints did not remove as much thiouracil per volume of cells as did the red cells of the nonleukemic patient. The final concentration of the drug in the plasma was less in the chronic leukemic blood than in the non-leukemic blood. These findings indicate that lymphocytes and granulocytes are very active in ingesting thiouracil from the plasma; the red cells are less active than are the white cells.

The distribution of thiouracil in various tissue fluids was compared with its concentration in the

TABLE VI

Distribution of thiouracil added to blood in vitro

\begin{tabular}{|c|c|c|c|c|c|c|}
\hline Diagnosis. . & & Obesity & $\begin{array}{l}\text { Coronary } \\
\text { occlusion }\end{array}$ & $\begin{array}{l}\text { Acute myelo- } \\
\text { genous leuk. }\end{array}$ & $\begin{array}{l}\text { Chronic myelo- } \\
\text { genous leuk. }\end{array}$ & $\begin{array}{l}\text { Chronic lympho- } \\
\text { genous leuk. }\end{array}$ \\
\hline $\begin{array}{l}\text { Thiouracil (mgm.per } \\
100 \mathrm{cc} \text { of whole } \\
\text { blood) }\end{array}$ & $\begin{array}{l}\text { White blood cells } \\
\text { Red blood cells } \\
\text { Total cells } \\
\text { Plasma } \\
\text { Plasma and cells } \\
\text { Whole blood }\end{array}$ & $\begin{array}{l}0.5 \\
2.1 \\
2.7 \\
1.5 \\
4.2 \\
4.6\end{array}$ & $\begin{array}{l}1.35 \\
1.54 \\
2.89 \\
3.12\end{array}$ & $\begin{array}{l}1.26 \\
0.18 \\
1.59 \\
2.02 \\
3.61 \\
3.44\end{array}$ & $\begin{array}{l}3.4 \\
0.3 \\
3.8 \\
1.0 \\
4.8 \\
4.0\end{array}$ & $\begin{array}{l}4.0 \\
0.5 \\
4.5 \\
1.0 \\
5.5 \\
4.6\end{array}$ \\
\hline $\begin{array}{r}\text { Hematocrit } \\
\text { (per cent) }\end{array}$ & $\begin{array}{l}\text { White blood cells } \\
\text { Red blood cells } \\
\text { Plasma }\end{array}$ & $\begin{array}{r}0.2 \\
39.9 \\
59.9\end{array}$ & $\begin{array}{r}0.1 \\
40.6 \\
59.3\end{array}$ & $\begin{array}{r}3.0 \\
15.0 \\
82.0\end{array}$ & $\begin{array}{r}7.6 \\
39.0 \\
53.4\end{array}$ & $\begin{array}{r}5.0 \\
30.0 \\
65.0\end{array}$ \\
\hline \multicolumn{2}{|l|}{ White blood count } & 12,250 & 7,550 & 48,000 & 96,000 & 160,000 \\
\hline
\end{tabular}


TABLE VII

Thiouracil in body fluids

\begin{tabular}{|c|c|c|c|c|}
\hline Type of fluid & Thiouracil in fluid & Thiouracil in blood & Thiouracil treatment & Diagnosis \\
\hline Cerebrospinal & $\begin{array}{c}\text { mgm. per } 100 \mathrm{cc} . \\
0.6 \\
1.0 \\
0.3 \\
0 \\
0.7 \\
0.5\end{array}$ & $\begin{array}{c}\text { mgm. per } 100 \text { cc. } \\
2.8 \\
1.2 \\
1.2 \\
1.2 \\
1.2 \\
2.0\end{array}$ & $\begin{array}{l}\text { grams } \\
0.4 \text {, daily for } 22 \text { days } \\
0.5 \text {, daily for } 10 \text { days } \\
0.6 \text {, daily for } 7 \text { days } \\
0.6 \text {, daily for } 3 \text { days } \\
1.0,2 \text { hrs. before } \\
1.0,2 \text { hrs. before }\end{array}$ & $\begin{array}{l}\text { Heart failure } \\
\text { Heart failure } \\
\text { Heart failure } \\
\text { Convalescent meningitis } \\
\text { Latent syphilis } \\
\text { Heart failure }\end{array}$ \\
\hline Edema & $\begin{array}{l}0.3 \\
0.6\end{array}$ & $\begin{array}{l}3.2 \\
1.2\end{array}$ & $\begin{array}{l}1.0 \text {, daily for } 3 \text { days } \\
0.6 \text {, daily for } 7 \text { days }\end{array}$ & $\begin{array}{l}\text { Heart failure } \\
\text { Heart failure }\end{array}$ \\
\hline Pericardial & 0.3 & 1.2 & 0.6 , daily for 7 days & Heart failure \\
\hline Chest & $\begin{array}{l}3.0 \\
3.2 \\
1.0\end{array}$ & $\begin{array}{l}2.8 \\
4.0 \\
2.8\end{array}$ & $\begin{array}{l}0.6 \text {, daily for } 6 \text { days } \\
0.5 \text {, daily for } 4 \text { days } \\
0.6 \text {, daily for } 4 \text { days }\end{array}$ & $\begin{array}{l}\text { Heart failure } \\
\text { Heart failure } \\
\text { Pleural effusion }\end{array}$ \\
\hline Ascitic & $\begin{array}{l}2.6 \\
2.0\end{array}$ & $\begin{array}{l}2.0 \\
2.0\end{array}$ & $\begin{array}{l}0.75 \text {, daily for } 7 \text { days } \\
0.75 \text {, daily for } 4 \text { days }\end{array}$ & $\begin{array}{l}\text { Laennec's cirrhosis } \\
\text { Laennec's cirrhosis }\end{array}$ \\
\hline Milk & $\begin{array}{r}12.0 \\
9.2\end{array}$ & $\begin{array}{l}4.0 \\
3.2\end{array}$ & $\begin{array}{l}\text { 1.0, } 2 \text { hrs. before } \\
1.0,2 \text { hrs. before }\end{array}$ & $\begin{array}{l}\text { Postpartum } \\
\text { Postpartum }\end{array}$ \\
\hline
\end{tabular}

blood (Table VII). The pericardial fluid was obtained at autopsy. The edema fluid was collected through a 20-gauge needle inserted into the dorsum of the ankle. The milk specimens were obtained with a breast pump. The cerebrospinal fluid, edema, and pericardial fluids were found to contain distinctly less thiouracil than did the whole blood. However, these fluids possessed about the same concentration of the drug as found in the plasma. The chest fluids and ascitic fluids contained essentially the same proportion of thiouracil as did the blood; however, milk was found to have 3 times as much.

The daily excretion of thiouracil in the urine was estimated with a group of patients, mostly thyrotoxics, treated with dosages ranging from 0.2 to 1.2 grams daily (Table VIII). The amount of the drug in the urine was, in general, about one-third of the total amount ingested; however, there was moderate variability in the quantity excreted by different individuals maintained on the same dosage.

Three patients with nephritis were studied in order to observe the effect of impaired kidney function on the excretion of thiouracil and on its accumulation in the blood. One patient with chronic glomerular nephritis and marked uremia was given 0.75 gram of the drug for 10 days, during the last 3 of which all urine was saved for analysis. During this time, the average daily amount of the drug excreted was $3 \mathrm{mgm}$., whereas in normal subjects with comparable treatment, the excretion is 100 times this amount. However, in spite of the failure of the nephritic patient to excrete the drug, the blood level did not exceed the normal range. Another patient with chronic glomerular nephritis and uremia, who was treated with 0.75 gram of thiouracil daily, excreted an average of $24 \mathrm{mgm}$. per day during a period of 7 days. As in the first case, the blood level remained normal. In a third patient with healed pyelonephritis and only moderate impairment of renal function, the average daily

TABLE VIII Excretion of thiouracil in the urine

\begin{tabular}{l|c|c|c|c}
\hline \hline \multirow{2}{*}{$\begin{array}{c}\text { Daily } \\
\text { dosage }\end{array}$} & \multicolumn{2}{|c|}{ Thiouracil in urine } & $\begin{array}{c}\text { Number of } \\
\text { determina- } \\
\text { tions }\end{array}$ & $\begin{array}{c}\text { Number of } \\
\text { patients }\end{array}$ \\
\cline { 2 - 5 } grams & Average & Range* & & \\
\cline { 2 - 5 } 1.2 & \multicolumn{2}{|c|}{ mgm. per day } & & \\
1.0 & 373 & 150 to 618 & 49 & 8 \\
0.8 & 249 & 75 to 482 & 50 & 8 \\
0.75 & 299 & 115 to 448 & 3 & 2 \\
0.6 & 324 & 218 to 388 & 6 & 2 \\
0.5 & 206 & 87 to 382 & 16 & 2 \\
0.4 & 96 & 65 to 152 & 6 & 2 \\
0.25 & 149 & 55 to 265 & 12 & 5 \\
0.2 & 101 & 84 to 132 & 6 & 2 \\
& 82 & 16 to 202 & 13 & 2 \\
\hline
\end{tabular}

* The values given include only the specimens obtained after the patient had received treatment for 3 days or more. 
excretion of thiouracil was only about 25 per cent of normal, but the blood level remained essentially normal. These observations indicate that the drug may be broken down by the body tissues. Our attention was first directed to the liver as possibly being the chief site for the breakdown of the drug. If such is the case, one might expect subjects with severe liver disease to show a greater rise in the thiouracil level of the blood than is shown in normal subjects. Two patients with severe cirrhosis were given 0.75 gram of thiouracil daily. All urine was saved and frequent blood specimens were obtained. However, the amount of the drug in the urine and the blood was repeatedly normal in each patient. The question then arose as to whether many tissues participated in the breakdown of thiouracil. Thereupon, we investigated the effect of isolated tissues by adding known amounts of the chemical to tissue slices in Warburg vessels.

\section{DESTRUCTION OF THIOURACIL BY TISSUE SLICES}

From 30 to $80 \mathrm{mgm}$. of rat liver, in the form of thin slices, were placed in each of 5 test tubes containing $2.7 \mathrm{cc}$. of a phosphate salt medium. To this was added $0.3 \mathrm{cc}$. of a solution containing $100 \mathrm{mgm}$. per cent of thiouracil. The tubes were shaken in a water bath at $38^{\circ} \mathrm{C}$. for varying intervals and then the remaining quantity of thiouracil was estimated in the tissue, as well as in the medium. Within 2 minutes, none of the drug was destroyed, but in 10 minutes, there was 14 per cent destruction; in 30 minutes, 17 per cent; in 1 hour, 20 per cent; and in 2 hours, 33 per cent.

In a series of experiments, we studied the breakdown of thiouracil produced by slices of kidney, pituitary, thyroid, adrenal, pancreas, and striated muscle. In the first experiment, thin slices of tissues, totalling in wet weight from 3 to $6 \mathrm{mgm}$., were placed in test tubes containing 5 cc. of phosphate medium and $0.48 \mathrm{mgm}$. of thiouracil. The tubes were shaken in a water bath at $38^{\circ} \mathrm{C}$. for 2 hours, during which time oxygen was passed over the surface of the medium. The $\mathrm{pH}$ of the solution was 7.4 at the beginning of the experiment and essentially the same at the end. At the end of the experiment,
TABLE IX

Destruction of thiouracil by tissue slices

\begin{tabular}{|c|c|c|c|c|}
\hline \multicolumn{2}{|c|}{ Experiment } & \multirow{2}{*}{\begin{tabular}{|c} 
Wet weight* \\
$m g m$. \\
67 \\
3 \\
14.8 \\
36.8 \\
61.1 \\
62.2
\end{tabular}} & \multirow{2}{*}{$\begin{array}{c}\text { Destruction } \\
\text { per cent } \\
47 \\
13 \\
72 \\
72 \\
5 \\
2 \\
\end{array}$} & \multirow{2}{*}{ 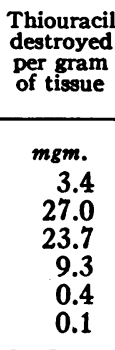 } \\
\hline No. 1 & $\begin{array}{l}\text { Kidney } \\
\text { Pituitary } \\
\text { Thyroid } \\
\text { Adrenal } \\
\text { Pancreas } \\
\text { Muscle }\end{array}$ & & & \\
\hline No. 2 & $\begin{array}{l}\text { Kidney } \\
\text { Liver } \\
\text { Pituitary } \\
\text { Thyroid } \\
\text { Adrenal } \\
\text { Pancreas } \\
\text { Muscle }\end{array}$ & $\begin{array}{c}91.2 \\
109.2 \\
7 \\
24.7 \\
66.6 \\
172.8 \\
79.4\end{array}$ & $\begin{array}{l}83 \\
90 \\
61 \\
50 \\
84 \\
39 \\
43\end{array}$ & $\begin{array}{r}4.4 \\
3.9 \\
41.3 \\
10.1 \\
6.2 \\
1.1 \\
2.5\end{array}$ \\
\hline No. 3 & $\begin{array}{l}\text { Kidney } \\
\text { Liver } \\
\text { Pituitary } \\
\text { Thyroid } \\
\text { Adrenal } \\
\text { Pancreas } \\
\text { Muscle }\end{array}$ & $\begin{array}{r}74.9 \\
187.1 \\
1.2 \\
18.9 \\
70.6 \\
276.1 \\
155.3\end{array}$ & $\begin{array}{r}42 \\
3 \\
76 \\
73 \\
22 \\
21 \\
14\end{array}$ & $\begin{array}{r}2.8 \\
0.1 \\
316.0 \\
19.0 \\
1.6 \\
0.4 \\
0.5\end{array}$ \\
\hline No. 4 & Liver & $\begin{array}{r}13.4 \\
37.4 \\
77.3 \\
198.6\end{array}$ & $\begin{array}{l}89 \\
61 \\
17 \\
16\end{array}$ & $\begin{array}{r}29.8 \\
7.2 \\
0.6 \\
0.2\end{array}$ \\
\hline \multirow[t]{2}{*}{ No. 5} & Liver & $\begin{array}{r}7.6 \\
41.0 \\
89.6 \\
191.2\end{array}$ & $\begin{array}{l}86 \\
65 \\
15 \\
12\end{array}$ & $\begin{array}{r}48.6 \\
7.2 \\
0.9 \\
0.3\end{array}$ \\
\hline & & 384.4 & 3 & 0.03 \\
\hline
\end{tabular}

* Wet weights were used rather than dry weights because drying at $100^{\circ} \mathrm{C}$. causes destruction of thiouracil.

the amount of thiouracil remaining in the medium and the tissues was determined. Two subsequent experiments were conducted using liver slices in addition to the others. These 2 experiments differed from the first in that Warburg vessels were used instead of test tubes, larger quantities of tissues were employed, and $\mathbf{0 . 5 0}$ mgm. of thiouracil was added. All of the tissues were active in destroying the drug (Table IX); in some instances, more than 75 per cent was destroyed. Less than 5 per cent of the drug was found in any of the tissues. When the amount of destruction of thiouracil was calculated on the basis of 1 gram of tissue, it was found that the pituitary tissue was the most active, while the thyroid and adrenal were next most active; muscle and pancreas were least active. How- 
ever, it soon became apparent that within certain limits, the more tissue present, the less was the total destruction. This apparent paradox was investigated in the case of liver slices (Experiments 4 and 5, Table IX). To a series of Warburg vessels containing $5 \mathrm{cc}$. of phosphate medium and $9 \mathrm{mgm}$. per cent thiouracil, were added thin slices of liver in widely varying quantities. The mixture was shaken in a water bath at $38^{\circ} \mathrm{C}$. for 2 hours. When $7.6 \mathrm{mgm}$. of liver slices were used, there was a destruction of 86 per cent of the thiouracil. With an increase in the amount of liver, there was a progressive decrease in the absolute quantity of drug destroyed, the destruction being only 3 per cent with $384 \mathrm{mgm}$. of liver. No destruction took place in the control flask, which contained the same constituents as the others, with the exception of the liver slices. A more extensive report on this phenomenon will be made later.

\section{DISTRIBUTION OF THIOURACIL IN TISSUES Autopsy specimens}

A group of patients with various diseases, bearing an essentially hopeless prognosis, were given thiouracil for one or more days preceding death. At autopsy, specimens were obtained from most of the tissues of the body. In the case of small organs, such as the adrenal and pituitary, essentially all of the tissue was used in the preparation of a fine suspension; with the larger structures, about 100 grams were used. Excess blood was squeezed out and washed from the surface and the tissue was then analyzed for its content of thiouracil by the method which is given in a separate report (1).

In conducting such a study, we had hopes of demonstrating in a crude manner the relative concentrations of the drug throughout the various tissues of the body. In interpreting the results, we have borne in mind the fact that all of the subjects studied were markedly abnormal in many ways. In most of the patients, there probably was an impairment in the absorption, distribution, and excretion of the drug. Furthermore, there were variations in the total dosage of the drug and in the interval from death until the analysis of the tissue. The data presented in the previous section suggest that some destruction of the drug might take place immediately

TABLE $X$

Distribution of thiouracil in tissues*

\begin{tabular}{|c|c|c|c|c|c|c|c|c|c|c|}
\hline Patient.................. & c. 0 . & M. A. & R. Y. & M. A. T. & W. $\mathbf{R}$. & C. $\mathbf{R}$. & R. I. & H. $O$. & Q. U. & M. 0 . \\
\hline Age (years) ......... & 60 & 72 & 54 & 60 & 24 & 60 & 65 & 60 & 69 & 73 \\
\hline Cause of death. & $\begin{array}{c}\text { Pneumonia. } \\
\text { pyelo- } \\
\text { nephritis }\end{array}$ & $\begin{array}{c}\text { Heart } \\
\text { failure }\end{array}$ & $\begin{array}{c}\text { Heart } \\
\text { failure }\end{array}$ & Uremia & $\begin{array}{c}\text { Acute } \\
\text { lymphatic } \\
\text { leukemia }\end{array}$ & $\begin{array}{c}\text { Cerebral } \\
\text { hemor- } \\
\text { rhage }\end{array}$ & $\underbrace{}_{\substack{\text { Pul- } \\
\text { monary } \\
\text { losis }}}$ & Uremia & $\begin{array}{l}\text { Bacte- } \\
\text { remia, } \\
\text { uremia }\end{array}$ & $\begin{array}{c}\text { Cerebral } \\
\text { hemor- } \\
\text { rhage }\end{array}$ \\
\hline $\begin{array}{l}\text { Hours post-mortem } \\
\text { Daily dosage (grams) } \\
\text { Total dosage (grams) } \\
\text { Pituitary } \\
\text { Adrenal } \\
\text { Thyroid } \\
\text { Pancreas } \\
\text { Testes } \\
\text { Ovaries } \\
\text { Bone marrow } \\
\text { Kidneys } \\
\text { Liver } \\
\text { Spleen } \\
\text { Muscle } \\
\text { Heart } \\
\text { Lungs } \\
\text { Brain } \\
\text { Prostate } \\
\text { Blood (mgm. per } 100 \text { cc.) }\end{array}$ & \begin{tabular}{r|}
3 \\
0.4 \\
8.8 \\
69.9 \\
41.0 \\
41.6 \\
2.7 \\
23.4 \\
115.0 \\
78.9 \\
6.4 \\
42.1 \\
4.7 \\
\\
45.8 \\
2.8
\end{tabular} & $\begin{array}{r}2 \\
0.5 \\
5.0 \\
\\
83.4 \\
152.0 \\
65.0 \\
209.0 \\
435.0 \\
97.0 \\
12.2 \\
38.6 \\
6.5\end{array}$ & $\begin{array}{r}14 \\
0.6 \\
4.2 \\
22.9 \\
21.7 \\
41.2 \\
31.1 \\
19.3 \\
\\
50.3 \\
11.7 \\
18.9 \\
11.2 \\
0\end{array}$ & $\begin{array}{r}17 \\
0.6 \\
3.6 \\
25.8 \\
35.6 \\
15.8 \\
11.8 \\
14.6 \\
40.6 \\
19.5 \\
12.2 \\
8.8 \\
0 \\
\\
\\
6.7 \\
2.8\end{array}$ & $\begin{array}{r}8 \\
0.6 \\
3.6 \\
118.0 \\
47.3 \\
214.0 \\
\\
\\
65.1 \\
204.0 \\
49.5 \\
21.2 \\
37.7 \\
8.2\end{array}$ & $\begin{array}{r}4 \\
1.2 \\
3.4 \\
26.0 \\
28.3 \\
1.9 \\
2.2 \\
2.8 \\
16.4 \\
1.5 \\
2.8 \\
1.0 \\
3.0 \\
1.1 \\
2.4 \\
2.2 \\
3.8\end{array}$ & $\begin{array}{c}336 \\
0.75 \\
2.5 \\
\\
8.5 \\
5.3 \\
\\
0 \\
\\
65.2 \\
0 \\
1.8\end{array}$ & $\begin{array}{l}12 \\
0.5 \\
0.5 \\
5.7 \\
9.2 \\
2.0\end{array}$ & $\begin{array}{r}13 \\
1.0 \\
1.0 \\
19.5 \\
11.7 \\
0.2 \\
0 \\
11.2 \\
0.2 \\
0.2 \\
2.7 \\
0.4 \\
1.6 \\
0.9 \\
0.5 \\
5.4\end{array}$ & $\begin{array}{l}29 \\
1.2 \\
2.2 \\
3.2 \\
2.1 \\
2.9 \\
1.7 \\
\\
1.5 \\
2.6 \\
1.1 \\
3.9 \\
1.4 \\
0.6 \\
0.4 \\
0.4 \\
3.4\end{array}$ \\
\hline
\end{tabular}

* The concentration of the drug in the tissues is expressed in terms of mgm. per 100 grams (dry weight) of tissue. With 3 cases, the fat-free dry weight was determined for each of the tissues but these values correlated so closely with the dry weight that this measure was discontinued. 
TABLE XI

Distribution of thiouracil in goiters

\begin{tabular}{|c|c|c|c|c|c|}
\hline Patient. . . . . . . . & M. K. & B. $\mathrm{O}$. & C. A. & M. G. & G. O. \\
\hline Diagnosis . . . . . . . & $\begin{array}{c}\text { Non-toxic } \\
\text { nodular goiter }\end{array}$ & $\begin{array}{l}\text { Non-toxic } \\
\text { nodular goiter }\end{array}$ & $\begin{array}{c}\text { Papillary } \\
\text { cystadenoma }\end{array}$ & $\begin{array}{c}\text { Toxic } \\
\text { nodular goiter }\end{array}$ & $\begin{array}{c}\text { Toxic } \\
\text { diffuse goiter }\end{array}$ \\
\hline $\begin{array}{l}\text { Daily dosage (grams) } \\
\text { Days treated } \\
\text { Relatively normal thyroid tissue* } \\
\text { Adenomatous thyroid tissue* } \\
\text { Blood level (mgm. per } 100 c c .)\end{array}$ & $\begin{array}{l}0.75 \\
12 \\
0.7 \\
6.8 \\
2.4\end{array}$ & $\begin{array}{r}0.6 \\
10 \\
3.1 \\
20.6 \\
3.2\end{array}$ & $\begin{array}{l}0.6 \\
10 \\
16.3 \\
.3 .0\end{array}$ & $\begin{array}{c}0.75 \\
9 \\
4.4 ; 3.9 \\
3.0\end{array}$ & $\begin{array}{c}0.5 \\
3 \\
0.3: 0.3 \\
0.4\end{array}$ \\
\hline
\end{tabular}

* Mgm. thiouracil for 100 grams (dry weight) of tissue.

after the death of the patient. Frequent analyses were made of the thiouracil content of a diffusely hyperplastic thyroid during an interval of 4 hours following thyroidectomy, but no changes were noted. Similar studies conducted with guinea pig livers and kidneys have shown essentially no changes during the first 2 hours after death of the animal but slight changes thereafter. Once alkaline extracts of the tissue are prepared (1), no change in the thiouracil content has been found to occur during a period of several days.

Almost all of the specimens examined (Table $\mathrm{X})$ were found to contain thiouracil. In the $\mathbf{5}$ cases dying within 3 days from the first dose of thiouracil, the greatest concentration of the drug was found in the pituitary, adrenals, bone marrow, and thyroid. In some of the 5 cases receiving thiouracil for 6 days or more, large quantities of the drug were concentrated in the bone marrow, thyroid, ovaries, and pituitary. The adrenals, kidneys, spleen, and pancreas also possessed a relatively large amount, but the muscle, liver, and testes contained a distinctly smaller quantity. In the patients who received treatment for more than 5 days, it was found that the concentration of the drug in most of the tissues was many times its concentration in the blood, in a few specimens being more than 50 times as great.

\section{Surgical specimens}

One patient who had been treated for thyrotoxicosis with thiouracil developed attacks of gall bladder colic which was found to be due to gall stones. At the time of the gall bladder operation, a small piece of liver and of skeletal muscle were removed for analysis of the thio- uracil content. She had received a total of 17.8 grams of thiouracil during a period of 27 days. The liver was found to contain $23.9 \mathrm{mgm}$. of the drug per 100 grams (dry weight) while the muscle contained $11.5 \mathrm{mgm}$. per 100 grams. Therefore, the concentration in each tissue was greater than was found in any of the autopsy specimens. Several factors may perhaps be involved to account for the difference; namely, the better metabolic condition of the patient, longer period of treatment, and shorter period of time for the destruction of the thiouracil by the tissue (analysis immediately after excision of the tissue).

Five patients with goiters were given from 0.5 gram to 0.75 gram of thiouracil for from 3 to 12 days preceding thyroidectomy and the tissue removed was analyzed for the content of the drug. Three of the patients had non-toxic nodular goiters while 2 had toxic goiters. Each of the patients with toxic goiters had received. treatment with potassium iodide for several weeks and their basal metabolic rates were normal, both at the time that thiouracil was begun and at the time of the operation.

The gland of one patient (M. K., Table XI) contained several nodules, one of which was grayish red, quite cellular, and friable; the other nodules were beefy red, contained a slight excess of colloid and a few strands of fibrous tissue. Microscopic examination revealed that the grayish-red nodule consisted of adenomatous tissue (Figure 7A) whereas the remainder of the gland was essentially normal (Figure 7B). The adenomatous tissue was found to have a concentration of thiouracil 10 times that present in the remainder of the tissue.

Patient B. O., who also had a non-toxic goiter, was found to have an adenoma of the thyroid. 


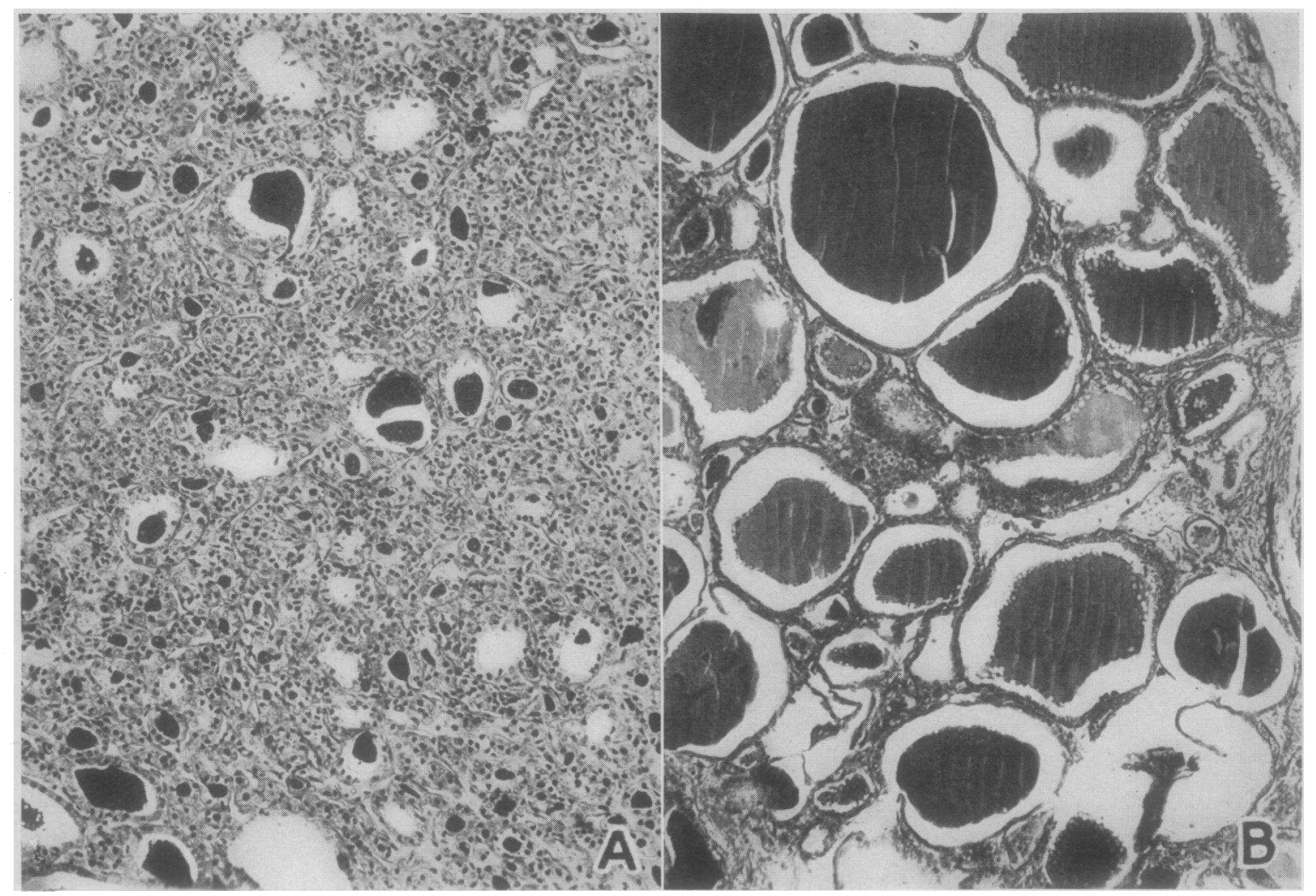

Fig. 7. Sections of a Non-Toxic Nodular Goiter (Patient M. K., Table Xi).

A. Adenomatous Tissue. B. Relatively Normal Tissue

The remainder of the gland contained a few scars, an increase in cell height in a few areas, and had slightly less colloid than normal. The adenomatous tissue was found to have a concentration of thiouracil which was 6 times that of the relatively normal tissue.

From patient C. A. was removed a papillary cystadenoma. No normal tissue was removed for comparison, but the concentration of the drug in the adenoma was similar to that in the adenoma of the previous patient.

Patient M. G. had a toxic nodular goiter. The tissue looked very much the same throughout, macroscopically and microscopically. The epithelium was flat and there was a slight excess of colloid. Two different samples of the gland were found to have essentially the same concentration of thiouracil, 4.4 and $3.9 \mathrm{mgm}$. per cent (dry weight of tissue).

Patient G. O. had a toxic goiter with diffuse hyperplasia. Microscopically, the gland was es- sentially normal. In each of 2 portions of the gland, the concentration of the drug was 0.3 mgm. per 100 grams (dry weight).

\section{SUMMARY}

1. Thiouracil is very rapidly absorbed from the gastro-intestinal tract and is readily excreted in the urine.

2. With dosages ranging from 0.2 to 1.2 grams daily, the concentration of the drug in the blood varied from 0.8 to $6.4 \mathrm{mgm}$. per cent, while the daily excretion in the urine varied from 16 to $618 \mathrm{mgm}$.

3. Most of the thiouracil in the blood is in the cells, the red cells containing a larger total amount but smaller concentration than the white cells.

4. Patients receiving the drug for several days preceding death were found at autopsy to have some of the substance in essentially all of the 
tissues of the body. Thiouracil was sometimes found in very large quantities in the bone marrow, thyroid, ovaries, and pituitary, while striated muscle, testes, and liver possessed relatively small concentrations.

5. Adenomata of the thyroid gland possessed a much greater concentration of thiouracil than did relatively normal thyroid tissue.

6. Cerebrospinal, edema, and pericardial fluids were found to contain distinctly less thiouracil than did whole blood; the concentration in pleural and ascitic fluid was about equal to that of blood, whereas milk contained about 3 times as much.

7. Thiouracil is rapidly destroyed by the contents of the stomach and the small intestines. It is also rapidly destroyed by many tissues of the body.

8. No thiouracil is excreted in the stools. The colon bacillus does not account for its absence since it does not destroy the drug.

\section{BIBLIOGRAPHY}

1. Williams, R. H., Jandorf, B. J., and Kay, G. A., Methods for the determination of thiouracil in tissues and body fluids. J. Lab. and Clin. Med., 1944, 29, 329.

2. Astwood, E. B., Treatment of hyperthyroidism with thiourea and thiouracil. J.A.M.A., 1943, 122, 78.

3. Williams, R. H., and Bissell, G. W., Thiouracil in the treatment of thyrotoxicosis. New England J. Med., 1943, 229, 97.

4. Grote, I. W., A new color reaction for soluble organic sulfur compounds. J. Biol. Chem., 1931, 93, 25.

5. Medes, G., Metabolism of sulfur. VI. Oxidation in the body of the sulfur-containing amino-acids and some of their partially oxidized derivatives. Biochem. J., 1937, 31, 1330.

6. Blood, F. R., and Lewis, H. B., The metabolism of sulfur. XXX. Thiourea. J. Biol. Chem., 1941, $139,413$.

7. Mendel, L. B., and Myers, V. C., The metabolism of some pyrimidine derivatives. Am. J. Physiol., 1910, $26,77$.

8. Williams, R. H., and Kay, G. A., Further studies on the absorption, distribution, and elimination of thiouracil. J. Clin. Endocrinol., in press. 